\title{
Entrepreneurial Social Network Development to Improve the Business Performance of Small Medium Enterprise: A Case Study of Hospitality Industries in Western Region
}

\author{
Hu Xuhua ${ }^{1}$, Adelaide Spio-Kwofie ${ }^{2}$, Michael Addai ${ }^{3}$, Bertha Danso ${ }^{4}$
}

Jiangsu University, School of Finance and Economics, Zhenjiang, China

\author{
*Corresponding Author: \\ Adelaide Spio-Kwofie \\ Email: adelaide.spio-kwofie@tpoly.edu.gh
}

\begin{abstract}
Western Region is known for its hospitality and tourism destinations and the cosmopolitan nature of the city has contributed to the increase in number of business institutions and hospitality industry is no exception. This study is based on entrepreneur social network development to improve business performance of the small medium hospitality industry. Social networking is a communicating strategy that allows SMEs to come together to reach out to customers as well as other SMEs which are geographical located in other to improve business activities and increase profit. Generally there are several benefits such as shared knowledge, opportunities, raising the hospitality's profile, increased confidence and connection associated with social networking. The study therefore recommend the use of social network by SMH entrepreneurs in Western Region to promote their business and by this, they stand the better chance of business boom.

Keywords: Small Medium Hospitality Industry (SMHI), Small Medium Hospitality (SMH) Social Networking
\end{abstract}

\section{INTRODUCTION}

Favourable economic effects of industrial clusters according to Newlands [1] have been observed for nearly a century. According to Malmberg [2], cluster is a geographical concentration of interrelated firms and institutions, again cluster result in enhanced returns and growth for firms in the cluster [3]. Although hospitality industries have had long history of successful destinations that offer natural features as well as unique heritage in time past, there has been a growing interest in studying the advantages of hospitalities concentrating in a particular venue.

The concentration of industries, firms and people in cities creates congestion and bids up the price of one of it valuable assets called land, yet three quarters of the world population lives in cities [4]. One of the dominant of perspective on sources of the competitive advantages of firms according to Knoben [5] is resource based view of the firm. Although entrepreneurs often consider individuals capabilities to recognise and exploit opportunities for profitable production of goods or services, [6] are of the view that differences in the rates of entrepreneurship are the result of differences in entrepreneurship opportunities and this contributes to differences in start up rates. To Porter [7] the concentration of firms of similar sectors might be beneficial due to the presences of specialised labour market and specialised suppliers which creates opportunities for highly specialised new start-ups.
According to Puga [8], one may perceived some advantages from having large local labour market, but what is the channel through which they work. Social networking refers to the platform for communication usually used in the marketing world of business. Again it can be referred to as group of individuals or firms that choose to communicate with one another through a preferred site the group has created for themselves [9]. Social Networking, according to $[10,11]$ involves practice of increasing the number of one's business by means of social contacts and connections. Although a lot of literatures have explained indicators that affect SME, [12] elaborated that entrepreneurs as owners of a firm has important role to play in regarding the successful performance of the business. To [13], the act of SME achievement is mostly influenced by certain external factors that such as economic condition, government policy, available funds and infrastructure [14], that the business is affected by the persons locus of control and likelihood of entrepreneur's ability to take risk. To [15] both locus of control and risk taking has no significant influence to SMEs achievement in business. This notwithstanding, $[10,15]$ are of the view that SMEs networking enable them get access to business achievements

Generally, social competence in terms of business performance is the way of analysing the capabilities of a group of entrepreneurs in building social relationship through social interrelation. According to [16], this analytical tool is used to 
establish social relationship with the entrepreneurs' employee, entrepreneur social closeness with the customer, entrepreneurs' ability to establish relation with funding organisations, entrepreneurs' social closeness with the authority such as government as well as the entrepreneurs' social relationship with other professional bodies [17].

Networking on the other hand is business relationship that is associated with more than one network [18] and these are seen from three components such as the performer, the activity, and the source in each network [19]. Networking don't just happen, it requires systematic investment in time and efforts towards the fostering of business relationships.

Social networking concept discusses the relationship that connects people in their group or communities in social structures $[18,19]$.

In effect, business network is about the firm, department, individuals', friends, colleagues, family, and employees through which the social network is established.

While social networking of SME in economic development and growth is crucial in developed countries, the developing countries are not exceptional.

SMEs performance is sometimes referred to the activities involving how well or poor an SME is performing in terms of financial and non-financial activities [20]. Activities such as return on investment, return on equity, return on capital, employee retention, market share are all used to assess the SMEs performance [21]. Some SMEs performance indicators too according to $[22,23]$ are the measurement of sale, customer relation, profit among others. These indictors help the SME have a better customer loyalty, better products quality, quality technology and a better development of product comparatively.

Economic activities in both developed and developing world don't just happen in space [24], therefore space and location which serve as centre for economic activities, needs to be taken into consideration because it facilitates economic development and industrialization.

Another important factor in SMEs performance is the human resource. This is the skills and knowledge ability of the personnel working in the firm. To [24, 25], the value of human resource ability to perform a task is acquired through an individual learning and experience and that its importance is nonnegotiable in SMEs.

Encouraging partnership of public and private SMEs network is integral to economic development because SMEs by their nature are more flexible and responsive [26], can pool resources together [27] as well as share the cost of $R \& D$, [28] training and marketing [29]. SEMs everywhere are now seeking local networks and support systems that can help break through the challenges of globalisation. In other to overcome business fold up, most SMEs are looking for the opportunity to form alliance, franchise as well as coming into joint ventures [28, 29].

Globally SMEs contribution to national growth is very significant and research confirms that SMEs are the engines of economic growth.

Ghana has been endowed with major natural resources that have been exploited for many years for economic growth and development [30]. Ghana's history of oil and gas exploration dates back to the $19^{\text {th }}$ century and it has been one of Africa's fastest growing economies over the past decade and the recent discoveries of oil make this goal seem even more achievable [31], but if such growth rates are to be maintained, Ghana will almost certainly need to undergo major advance with regards to industrial capabilities [30, 31]. In Ghana it is easy to find cities and towns that have developed around mineral extraction zones, and there seems to be a reciprocal relationship between the developments of mines and cities. The Western Region of Ghana has the largest concentration of bauxite, manganese, iron ore, diamonds [30, 32] and the region is also seen as the source of oil extraction [30].

The availability of industries, transportation, administration and tourism has imperted to the positively development of towns and cities along the coastal belt [33], and the discovery of oil has also contributed significantly to the springing up of many Small Medium Hospitality Industries (SMHI) along Ghana's Jubilee oil zone especially Western Region.

Despite the entrepreneurial activities along the coastal oil zone, the closet settlement to the oil discoveries is Effasu, about 60kn from the oil zone [30]. Efasu, a rural fishing community, has no basic infrastructures for economic activity such as air port, sea port, hospitality facilities, extensive roads necessary to support the oil activities offshore [30, 34]. The nearest city to the oil discovery zone is the SekondiTakoradi, about $188 \mathrm{~km}$ from Effasu [35]. As it is common to any fertile ground for economic boom, the oil discovery and it drilling activities has brought foreign investors of diverse business activities. These investors, in turn seek hospitality services, thus accommodation, food and beverage and other services in hotels in the region. The hospitality industry in Western Region is one of the fastest growing sectors of the economy and has seen more hotels springing up in the region. The SMHI is involve in business activities 
such as accommodation, food and beverage, leisure to people away from home and provide friendly reception and entertainment $[36,37]$.

Despite the SMHIs contribution to the nation's economy, they are not accorded the legitimate support from concern quarters and these tend to hinder the business ability to perform locally and globally. Although a lot of SMHIs has sprung up due to the oil discovery, the entrepreneurs lack capacity to identify new markets, constraints on modernization and expansion [37] inability to hire qualified skills, bureaucratic delays [38] coupled with various rules from government [39], has led to many SMHIs either downsizing it employees or folding $[38,40]$ and some eventually turning the hotel rooms into domestic rented apartment.

Looking at SMHIs importance to economic growth, the industry is expected to grow through collaborative linkages with other similar ventures. The benefits that SMEs experience from being located in regions where many other firms are concentrated have been said by many researchers as important regional resources that supply enterprise [18], there is lack of evidence regarding entrepreneurial social and business network development to improve the SMHIs performance in Western Region.

Owing to segmentation of the market, SMHIs have increased and it therefore behoves on the entrepreneurs to curve a niche that will attract customers to the facilities daily. This calls for active participation of the entrepreneurs in hospitality and it related activities through social networking. On the other hand the local workforce also can help by engaging the services of SMEs that are into transportation, suppliers of food and beverage, telecommunication, tourism among others which in effect will connect hospitality entrepreneurs together.

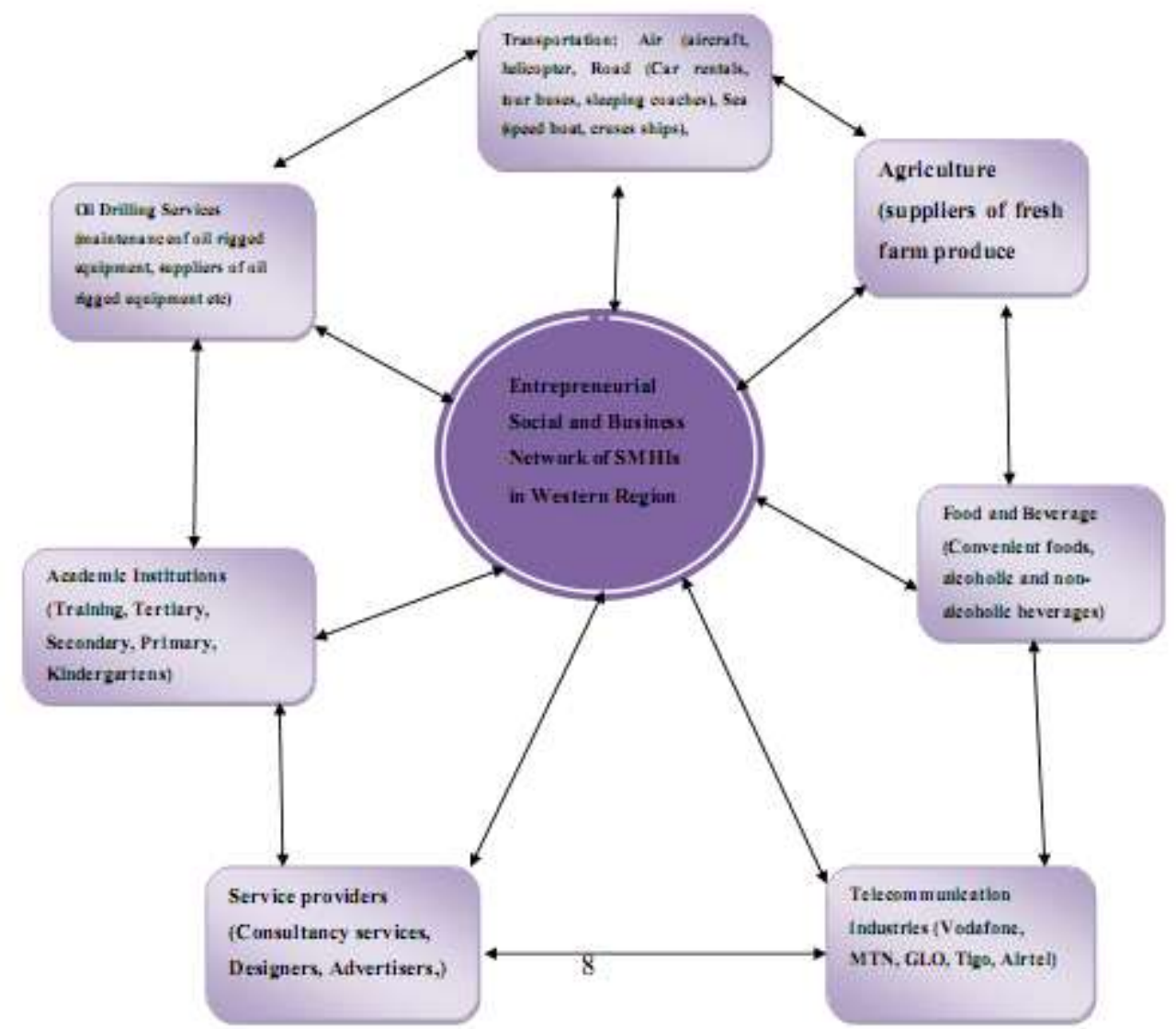

Fig-1: Entrepreneurial Social Network of SMHIs in Western Region

(Authors own concept design 2016)

From the diagram, one could deduce that no business is an island, each firms business activity is inter connected to each other due to the geographical proximity and this lead to increase in performance. Generally there are several benefits associated with social networking, so if Small Medium Hospitality (SMH) entrepreneurs in Western Region are able to promote their business through social networking they stand the better chance of business boom.

Enumerated below are some of benefits of social networking in promoting business as proposed by [41-43]. 
SMHIs social networking allows the business to reach out to potential customers without spending exorbitant amount of money on adverting and still stay in touch with your current customers, promote the business, connected to other business, gives you chance to reach out to new customers, get introduction from your existing contacts and opens door for expansion. In summery the benefits are shared knowledge, opportunities, raising the SMHIs profile, increased confidences and connections. SMHIs services are highly perishable and competitive in nature so entrepreneurs should take advantage and interact with local firms to improve business performance. Again the study suggests that entrepreneurs of SMHIs should cooperate with other SMEs that are geographically concentrated within the region through social networking to increase sales.

\section{REFERENCES}

1. Newlands, D. (2003). Competition and cooperation in industrial clusters: the implications for public policy. European Planning Studies, 11(5), 521-532.

2. Malmberg, A. (2003). Beyond the cluster-local milieus and global connections. Remaking the global economy, 145-159.

3. Braunerhjelm, P., \& Borgman, B. (2004). Geographical concentration, entrepreneurship and regional growth: Evidence from regional data in Sweden, 1975-99. Regional Studies, 38(8), 929947.

4. Iracheta, A., McCarthy, L., Ahrentzen, S., Waldheim, C., Watson, G. B., Zell, M., ... \& Massood, P. J. (2012). Sustaining cities: Urban policies, practices, and perceptions. L. Krause (Ed.). Rutgers University Press.

5. Knoben, J. (2011). The geographic distance of relocation search: an extended resource-based perspective. Economic Geography, 87(4), 371-392.

6. Knoben, J., Ponds, R., \& van Oort, F. (2011). Employment from new firm formation in the Netherlands: Agglomeration economies and the Knowledge Spillover Theory of Entrepreneurship. Entrepreneurship and Regional Development, 23(3-4), 135-157.

7. Porter, M. E. (2000). Location, competition, and economic development: Local clusters in a global economy. Economic development quarterly, 14(1), 15-34.

8. Puga, D. (2010). The magnitude and causes of agglomeration economies. Journal of Regional Science, 50(1), 203-219.

9. Lim, W. (2010). The Effects of social media networks in the hospitality industry.

10. Ellison, N. B. (2007). Social network sites: Definition, history, and scholarship. Journal of Computer-Mediated Communication, 13(1), 210230.

11. Szarka, J. (1990). Networking and small firms. International small business journal, 8(2), 10-22.
12. Elfring, T., \& Hulsink, W. (2003). Networks in entrepreneurship: The case of high-technology firms. Small business economics, 21(4), 409-422.

13. Zhang, Y., \& Si, C. (2008). The impacts of external factors on the growth of Chinese entrepreneurial enterprises: An empirical study. Journal of small business and enterprise development, 15(4), 689703.

14. Littunen, H. (2000). Entrepreneurship and the characteristics of the entrepreneurial personality. International Journal of Entrepreneurial Behavior \& Research, 6(6), 295-310.

15. Ong, J. W., Ismail, H. B., \& Goh, G. G. G. (2010). The competitive advantage of small and medium enterprises (SMEs): The role of entrepreneurship and luck. Journal of Small Business \& Entrepreneurship, 23(3), 373-391.

16. Cho, H., Gay, G., Davidson, B., \& Ingraffea, A. (2007). Social networks, communication styles, and learning performance in a CSCL community. Computers \& Education, 49(2), 309-329.

17. Earl, J., \& Schussman, A. (2003). The new site of activism: on-line organizations, movement entrepreneurs, and the changing location of social movement decision-making. Research in Social Movements, Conflicts and Change, 24, 155-187.

18. Anderson, J. C., Håkansson, H., \& Johanson, J. (1994). Dyadic business relationships within a business network context. The Journal of Marketing, 1-15.

19. BarNir, A., \& Smith, K. A. (2002). Interfirm alliances in the small business: The role of social networks. Journal of small Business management, 40(3), 219-232.

20. Appiah Fening, F., Pesakovic, G., \& Amaria, P. (2008). Relationship between quality management practices and the performance of small and medium size enterprises (SMEs) in Ghana. International Journal of Quality \& Reliability Management, 25(7), 694-708.

21. Van Auken, H., Madrid-Guijarro, A., \& GarciaPerez-de-Lema, D. (2008). Innovation and performance in Spanish manufacturing SMEs. International Journal of Entrepreneurship and Innovation Management, 8(1), 36-56.

22. Anderson, M., \& Sohal, A. S. (1999). A study of the relationship between quality management practices and performance in small businesses. International Journal of quality \& Reliability management, 16(9), 859-877.

23. Richard, P. J., Devinney, T. M., Yip, G. S., \& Johnson, G. (2009). Measuring organizational performance: Towards methodological best practice. Journal of management.

24. Kotler, P. (2002). Marketing places. Simon and Schuster.

25. Moilanen, T., \& Rainisto, S. (2009). How to brand nations, cities and destinations. A planning book for place branding. UK: Palgrave MacMillan, 65-75. 
26. Üztel, H., \& Martin, S. (1998). Local partnership for economic development: Business links and the restructuring of SME support networks in the United Kingdom. Economic Development Quarterly, 12(3), 266-278.

27. Morgan, K. (2007). The learning region: institutions, innovation and regional renewal. Regional studies, 41(S1), S147-S159.

28. Christian, A., Dirk, C., \& Alfred, S. (2009). Innovation success of non-R\&D-performers: substituting technology by management in SMEs. Small Business Economics, 33(1), 35-58.

29. Jeffrey, J, S. (2008). Networking futures: The movements against corporate globalization: Duke University Press.

30. Emmanuel, A. S. (2014). Economic effects of oil and gas production and management on the Ghanaian economy. European Scientific Journal, 10(10).

31. John, S., \& Bennet, K. (2012). An enterprise map of Ghana (Vol. 2): International Growth Centre in association with the London Publishing Partnership.

32. Lesley, W. A., Julia, M. V, \& Hilary, Z. L. (2012). Public-Private Partnerships for Maritime Security Capacity-Building in the Gulf of Guinea: DTIC Document.

33. Udaya, S. N. (2005). Integrated coastal zone management in Vietnam: Present potentials and future challenges. Ocean \& coastal management, 48(9), 813-827.

34. Philip, A. S., \& Roland, D. (2011). China, oil and global politics: Routledge.

35. Franklin, O. O. (2013). Windfalls, wipeouts, and local economic development: A study of an emerging oil city in West Africa. Local Economy, 28(4), 429-443.

36. Peter, J. (2002). Introduction to hospitality operations: an indispensable guide to the industry: Cengage Learning EMEA.

37. Nickson, D. P., Baum, T. G., Losekoot, E., Morrison, A. J., \& Frochot, I. (2002). Skills, organisational performance and economic activity in the hospitality industry: a literature review.

38. Irena, G. (2006). Skills, training and human resource development: a critical text: Palgrave Macmillan.

39. Aidarkulovich, S. G. (2015). Does the adoption of customer and competitor orientations make small hospitality businesses more entrepreneurial? Evidence from Kazakhstan. International Journal of Contemporary Hospitality Management, 27(1), 71-86.

40. Eric, J. P., \& Amitabh, R. S. (2003). Measuring and comparing volume flexibility in the capital goods industry. Production and Operations Management, 12(4), 480-501.

41. Robert, M. G. C. (2004). Factors associated with formal networking in regional small business: some findings from a study of Swedish SMEs. Journal of Small Business and Enterprise Development, 11(1), 60-74.

42. John, M. M. F., \& Deepak, D. K. (2010). The influence of international networks on internationalization speed and performance: A study of Czech SMEs. Journal of World Business, 45(3), 197-205.

43. Lianxi, Z., Wei-ping, W., \& Xueming, L. (2007). Internationalization and the performance of bornglobal SMEs: the mediating role of social networks. Journal of International Business Studies, 673-690. 